\title{
Feminist disability studies vs discrimination of women with disabilities
}

Abstract: Tomasz Kasprzak, Feminist disability studies vs discrimination of women with disabilities. Interdisciplinary Contexts of Special Pedagogy, no. 24, Poznan 2019. Pp. 127-138. Adam Mickiewicz University Press. ISSN 2300-391X. DOI: https://doi. org/10.14746/ikps.2019.24.07

Disabled women are often treated as if they were deprived of feelings or desires. They are exposed to discrimination not only because of disability, but also because of gender (multiple discrimination). Feminist disability studies are an interdisciplinary field of research into the socio-political situation of women with disabilities.

KEY WORDS: gender, disability, women's studies, feminist studies

As a disabled woman, I felt a deep sense of alienation from the nondisabled feminists and anger that there seemed to be an assumption that they were "on the same side" as me

Jenny Morris ${ }^{1}$

\section{Foreword}

For a long time, disability was thought about in terms of socalled individual (medical) model, where the phenomenon of disa-

1 J. Morris, Feminism and Disability, “Feminist Review” 1993, no. 43. 
bility was regarded as the personal tragedy of an individual or the consequence of a diseases ${ }^{2}$. The individual paradigm of perceiving disability focused mainly on a strive to separate persons with disabilities from the other "normal" part of the society. It is a reflection of the model of hospital as place for gravely ill persons. The crowning of such perception of disability is, among other things, the theory of social stigma ${ }^{3}$.

As the emancipatory movement of persons with disabilities developed in the 1960s, the perception of the disability phenomenon underwent major transformation. This movement manifested itself in mass protests of persons with disabilities in the United States, mainly caused by delays in the implementation of the Rehabilitation Act prohibiting discrimination against persons with disabilities ${ }^{4}$. In the United Kingdom, the history of the movement was mainly associated with the activity of the Union of the Physically Impaired Against Segregation, UPIAS). The union consisted of a small group of physically impaired persons, and their goal was to eliminate institutional care for persons with disabilities and to ensure their full participation in social life, independent existence, professional activity and ability to make their own choices in life 5 .

The social model of disability is a challenge to discrimination and marginalization of persons with disabilities, combining civil rights and political activism. It is also a powerful tool in driving social and political changes, discussion on social and historical re-

2 B. Kowalska et al., Studia nad niepetnosprawnością a wyobraźnia socjologiczna, „Studia Socjologiczne” 2014, no. 2, p. 226.

${ }^{3}$ B. Gąciarz, Przemyśleć niepetnosprawność na nowo. Od instytucji państwa opiekuńczego do integracji i aktywizacji społecznej, „Studia Socjologiczna” 2014, no. 2, p. 19.

${ }^{4}$ In the early 1970s, a law was passed granting civil rights to persons with disabilities, which gave foundations for the American version of a social model of disability as a minority model. More in: A. Twardowski, Społeczny model niepetnosprawności - analiza krytyczna, „Studia Edukacyjne” 2018, no. 48, p. 102.

${ }^{5}$ A. Twardowski, Społeczny model niepetnosprawności - analiza krytyczna, „Studia Edukacyjne” 2018, no. 48, p. 102. 
pression against persons with disabilities and in research6. Jenny Morris emphasizes that the Movement for the rights of persons with disabilities, which was dominated by men, neglected the issues of sexuality and reproduction - the area particularly important in the life of women. Consequently, disabled women felt marginalized by the very movement that was supposed to represent them as disabled persons ${ }^{7}$.

The purpose of this article is to present a description of feminist disability studies and their development over the last 30 years. The first part of the article presents basic assumptions of feminist studies, focusing in particular on three main categories of feminist theories. Next, the article presents the genesis and idea of feminist disability studies and the focus areas of feminist studies on disability.

\section{Development of feminist studies}

Feminist studies developed spontaneously, without a coherent theory. Feminist studies focused mainly on the organisation of courses and research concerning various aspects of situations and experiences of women ${ }^{8}$. The most visible form of increased social and political activity of women took place in the 1960s and was associated with the American Women's Liberation Movement. Ewa Gontarczyk notes that within the movement evolved the feminist studies, often referred to as women's studies or female studies ${ }^{9}$.

It is difficult to find an unequivocal definition of feminism in the literature on the subject. It means movements, ideologies and doctrines that discuss legal, political and social equality of women and

${ }^{6} \mathrm{~J}$. Owens, Exploring the critiques of the social model of disability: the transformative possibility of Arendt's nation of power, "Sociology of Health and Illness" 2015, no. 3.

7 J. Morris, Introduction, [in:] Encounters with strangers. Feminist and disability, ed. J. Morris, The Women's Press, London 1996, p. 2.

8 E. Gontarczyk, Kobiecość i męskość jako categories social-cultural w studiach feminist. Perspektywa socjologiczno-pedagogiczna, Poznań 1995, p. 59.

${ }^{9}$ Ibidem. 
men ${ }^{10}$. Feminism is a complex concept. The sociologist Judith Lorber identified three main categories of feminist theories, her criterion being their attitude to the existing cultural construct of femininity and masculinity. The author lists: gender-reform feminism, genderresistance feminism and gender-rebellion feminism ${ }^{11}$.

According to the gender-reform feminism, there are more similarities than differences between men and women. Supporters of the gender-reform feminism want women to have, the same as men, the possibility of full participation in all areas of social life. Lober identified four types of the gender-reform feminism, primarily focusing on changing the existing forms of femininity and masculinity. These types are: liberal feminism, Marxist feminism, socialist feminism and "Third World" (so-called developmental) feminism. Supporters of the gender-resistance feminism focus mainly on the differences between female and male ideas and experiences. The researcher stresses the fact that in order to do away with male dominance, women must create their own organizations and communities. In this category, Lober includes: radical, lesbian, psychoanalytical and stand-point femisisms. The last, gender-rebellion feminism, also referred to as the "third wave" of feminism, departs from the conceptualization of biological gender and cultural gender, which are typical of the first and second waves of feminism. The genderrebellion feminism opposes the dominant constructs of cultural gender and it consists of the following trends: multiracial feminism, men's feminism, social constructivism feminist, postmodern feminism and the queer theory ${ }^{12}$.

There is currently a discussion in progress associated with defining and developing the feminist theory - its future and directions for development. The large variety and number of problems dis-

${ }^{10} \mathrm{~J}$. Helias, W. Jedlecka, Urzeczywistnianie idei feminizmu w ogólnoświatowym dyskursie o kobietach, E-wydawnictwo. Prawnicza i Ekonomiczna Biblioteka Cyfrowa, Wrocław 2018.

${ }^{11}$ C.M. Renzetti, D.J. Curran, Kobiety, mężczyźni i spoteczeństwo, translated by A. Gromkowska-Melosik, Wydawnictwo Naukowe PWN, Warszawa 2005, p. 33.

12 Ibidem, p. 33-36. 
cussed in the contemporary feminist literature show the complexity of feminism and its theories ${ }^{13}$. At the same time, the diversity of feminism is the cause of its problems. It is important to emphasize the phenomenon of the "fossilization of the movement" and its division into segments that cease to react to one another. Rosalind Delmar notes that,

instead of an internal dialogue, there are names of respective parts: radical feminists, Marxist feminists, lesbian separatists, color women etc. Each of the groups carefully protects its own sense of identity. Each believes that it is the most valuable trend of feminism and ignores and strongly criticizes the other ${ }^{14}$.

Jonathan H. Turner shows that female sociologists did not affect the shape of their domain. Sociology in itself is so fragmented that it is difficult to make a holistic change starting from different theoretical perspectives. According to the researcher, feminism would have to develop a single concept and, beginning with that concept, fight for an overall change in sociology ${ }^{15}$. Joan Acker proposes developing a feminist paradigm that would: (1) enable understanding the class and State structure, the social upheaval and militarism; (2) place women and their life centrally in the process of interpreting social relations as a whole; (3) build a methodology that would generate knowledge more for women than about women in all different situations ${ }^{16}$.

In social awareness, feminism functions as an emancipatory movement whose supporters (including female supporters) make demands associated with the "battle of the sexes" that is supposed to lead to a social revolution and destroy the traditional order ${ }^{17}$.

${ }^{13}$ E. Gontarczyk, op. cit., p. 78.

14 C.M. Renzetti, D.J. Curran, op. cit., p. 33, after: R. Delmar, What is feminism?, [in:] What is feminism?, ed. J. Mitchell \& A. Oakley, New York 1986.

15 J.H. Turner, Struktura teorii socjologicznej. Wydanie nowe, Warszawa 2004, s. 674.

16 Ibidem, p. 673.

17 A. Zygmunt, Feminizm a symboliczna ideologia, „Oblicza Komunikacji” 2009, vol. 2, p. 338. 
Griselda Pollock emphasizes that the "term 'feminist' functions as a perpetual provocation to women engaged in feminist scholarship, as much as to other scholars and theorists."18

\section{Feminist disability studies - the female perspective of disability?}

Until recently, disabled women were invisible in feminist movements. The idea of strong and competent women was in conflict with disability stereotypes. Disabled feminists criticized research conducted by the feminist movement, mainly for excluding the experiences of disabled women from feminist analysis. Feminist research, whose assumption was to integrate the diversity of women's experiences based on race and sexual orientation excluded disabled women. There was a breakthrough in the early 1980s, associated with Gwyneth Matthews' study based on interviews with 40 disabled women. Next, in 1984, the US President's Committee on Employment of the Physically Handicapped developed a report confirming the unequal status of disabled women in terms of education and professional activity compared disabled men. In 1985, Marry Deegan and Nancy Brooks published an extensive monograph. Eleven of its chapters were fully devoted to the disability of women, lack of information on their life and experiences, and the need for change in their living conditions that contribute to the consolidation of social inequalities experienced by disabled women ${ }^{19}$.

In recent decades, persons with disabilities and their supporters gained a lot in their struggle for civil rights and social integration. Regardless of the achievements already made by the community of disabled persons and hopes for the future ones, it should be noted

${ }^{18}$ G. Pollock, Polityki teorii: pokolenia i geografie. Teoria feministyczna $i$ historie historii sztuki, translated by M. Bryl, “Artium Quaestiones” 1997, no. VIII, p. 158.

${ }^{19}$ Ch.M. Tilley, Health Care for Women with Physical Disabilities: Literature Review and Theory, "Sexuality and Disability" 1998, no. 2. 
that disabled women are in a relatively less advantageous position than disabled men. Research conducted in many states shows that disabled women face more inconveniences than disabled men, e.g. in terms of ensuring independent life, education, healthcare, social care or access to culture ${ }^{20}$. Feminist activists note that the social forces and processes that construct and shape both gender and disability are closely linked. They include: Jenny Morris, Sally French, Karin Barron, Rosemary Garland-Thomson, Susan Wendall, Liz Crow.

Feminist disability studies dismiss the idea that disability is not a "defect", "lack" or excess". They define disability from the social rather than the medical perspective. Disability is a cultural interpretation of human changeability, not "innate inferiority", "pathology to be cured" or "undesirable property to be eliminated" 21 . According to Rosemarie Gerland-Thomson, feminist disability studies: first of all, tend to avoid medical diagnostic categories of disability. They analyze in what way persons with a broad range of physical, intellectual and emotional differences are excluded and presented as "deficient" by the abled society. Secondly, they use a precise language that may very often seem intricate. They use the term "properties that we consider disabled" rather than words like "deformations" or "anomalies"22. The author shows that the purpose of her first use of the term "feminist disability studies" was to combine the feminist theory with disability research. In her article Integrating Disability, Transforming Feminist Theory, Gerland-Thomson observes

${ }^{20}$ Antonina Ostrowska notes that such obstacles as limited activity on the labor market, stereotypes, prejudices, negative emotions, problems with communication, higher costs of living or social passivity may be encountered by both men and women. However, disability research and analyses show that, in the case of women, this is a much more discriminatory factor than in the case of men. She discusses the topic in more detail in: A. Ostrowska, Niepetnosprawni w społeczeństwie 1993-2013, Wydawnictwo IFiS PAN, Warszawa 2010, p. 45-46.

${ }^{21}$ R. Garland-Thomson, Feminist Disability Studies, "Journal of Women in Culture and Society" 2005, no. 2, p. 1558.

22 Ibidem, p. 1558-1559. 
that " integrating disability as a category of analysis and a system of representation deepens, expands, and challenges feminist theory" 23 .

Gerland-Thomson notes that the integration of disability with the feminist theory is generative, broadens common enquiries and questions the existing assumptions concerning disability. The researcher is in the front of recognizing feminist disability studies as a domain with separate methodology. Their goal is to prevent prejudices, understand disability as a politicized problem and build a community for all. The claims that feminist disability studies want to abolish stereotypes concerning disabled persons and their main goal is to undermine the dominant assumptions about the life of persons with disabilities ${ }^{24}$.

Feminist analyses of female oppression used the body as the tool for political activity and protests, and introduced the body to scholarly conceptualizations of the patriarchate. Shulamith Firestone in The Dialectic of Sex derives the system of gender inequalities directly from various reproductive functions of the female and male bodies $^{25}$. Agnieszka Wołowicz-Ruszkowska observes in her research that disability, which causes numerous changes in body functions (changes in proportions, ability, aesthetic criteria), triggers anxiety, especially in women with acquired disability or in the case of progressing disability. The respondent women also feared that their ability and body performance would continue deteriorating ${ }^{26}$. Undoubtedly, the body is highly idealized and objectivized in Western societies and social pressure to shape and normalize one's body is strong 27 . In Wołowicz-Ruszkowska's research, the respond-

${ }^{23}$ R. Gerland-Thomson, Integrating disability transforming feminist, "NWSA Journal" 2002 , no. 3, p. 1 .

24 Ibidem, p. 3-5.

25 Ch. Silling, Socjologia ciała, translated by M. Skowrońska, Wydawnictwo Naukowe PWN, Warszawa 2010, p. 45-46.

${ }^{26}$ A. Wołowicz-Ruszkowska, Zanikanie? Trajektorie tożsamości kobiet z niepetnosprawnościa, Wydawnictwo Akademii Pedagogiki Specjalnej, Warszawa 2013, p. 7.

27 C. Ahlvik-Harju, Disturbing bodies - reimagining comforting narratives of embodiment through feminist disability studies, "Scandinavian Journal of Disability Research" 2015, p. 5-7. 
ents, both with acquired and congenital disabilities, look for ways to accept their own body 28 .

Research conducted by Katarzyna Piątek shows that one of the basic aspects of disability is its impact of self-esteem, image and perception of oneself in relations with others. The experiences of women with disabilities concerning the image of their own bodies and social reactions to changes in their appearance and adaptation to those changes clearly show how important external appearance is nowadays. The respondent women emphasized difficulties associated with accepting their own corporeality after acquiring disability ${ }^{29}$.

Susanah B. Mintz in her work Unruly Bodies analyzed the life stories of eight women with disabilities. She wanted to better understand how the categories of gender and disability cooperate in shaping the identity of a woman, this way questioning the common concepts of disability as deviation, helplessness and dependence. Life stories concerning bodily differences show complex links between subjective experiencing of disability and its cultural narrative, being an example of how narratives about a "normal body" may hurt persons who embody something different. These stories may support feminist studies on disability in confrontation with the border of out understanding of human diversity, the physicality of the body and the social categories that interpret differences in corporeality ${ }^{30}$.

Apart from experimenting with the body, feminist disability studies discuss the problem of violence against disabled women. Researchers - Helen Meekosha, Lesley Chenoweth, Jeane Neath note that women with disabilities are more exposed to violence than abled persons. Chenoweth, based on government reports on institutional malpractices, builds a feminist analysis of disability in which

28 A. Wołowicz-Ruszkowska, op. cit.

${ }^{29}$ K. Piątek, Szanse i zagrożenia w funkcjonowaniu kobiet $z$ niepetnosprawnościa. Studium socjologiczne, [in:] Polscy niepetnosprawni. Pomiędzy deklaracjami a realiami, ed. B. Gąciarz, S. Rudnicki, D. Żuchowska-Skiba, Wydawnictwo AGH, Kraków 2015, p. 93.

${ }^{30}$ C. Ahlvik-Harju, op. cit., p. 5-7. 
she analyses the issue of sexual and physical abuse of women with disabilities. Noting the quiet and invisible nature of the social problem of violence, she emphasizes the existence of the following social assumptions ${ }^{31}$ :

-Women with disabilities do not have the skills or competencies to be a mother, which is probably why they do not establish intimate relationships;

-Women with disabilities should not be treated seriously;

-Women with disabilities are perceived as "sexless", whereas women with intellectual disabilities as promiscuous ${ }^{32}$.

A vast majority of literature discussing the problem of disabled women presents personal relations with the experience of physical disability. Some women speak with anger, the bitterness of isolation, despair and helplessness, while other disabled women celebrate their own successes. Survival in the contemporary society that treats women as products manifesting the male success means that women with disabilities have to fight with being treated as "defective goods". Obviously, not many women actually meet the standards imposed and them and those who fail to do so are considered not only as "unattractive" but mainly as "abnormal" 33 .

\section{Conclusions}

Scholarly research in this domain is relatively new and limited to a few important monographs. However, these were sufficient to

31 J.M. Marys, Feminist disability theory: domestic violence against women with a disability "Disability\&Society" 2007, no. 2, p. 150-151.

32Sexual abuse of disabled women has attracted some scholarly attention in recent years. Corbett J. O'Toole observes that, for the last or three years, there have been more sexual assaults on disabled women than on abled women. It seems contradictory that, on the one hand, women with disabilities are considered sexless but, on the other hand, they are more exposed to sexual abuse than abled women. More in: C.J. O'Toole, Violence and sexual assault plague many disabled women, New Directions for Women 1990, p. 17-20.

33 Ch.M. Tilley, op. cit., p. 95. 
provide information on the social and economic situation of disabled women. Most scholarly publications concerned the identification of barriers that disabled women encounter in the contemporary society and the extent to which their life is more difficult than the life of abled women or disabled men ${ }^{34}$. Undoubtedly, disabled women face contradictory expectations and standards that they cannot meet.

\section{Bibliography}

Ahlvik-Harju C., Disturbing bodies - reimagining comforting narratives of embodiment through feminist disability studies, "Scandinavian Journal of Disability Research" 2015, p. 5-7.

Gąciarz B., Przemyśleć niepetnosprawność na nowo. Od instytucji państwa opiekuńczego do integracji i aktywizacji społecznej, "Studia Socjologiczne” 2014, no. 2.

Gerland-Thomson R., Integrating disability transforming feminist, "NWSA Journal" 2002, no. 3, p. 1.

Garland-Thomson R., Feminist Disability Studies, "Journal of Women in Culture and Society" 2005, no. 2.

Gontarczyk E., Kobiecość i męskość jako kategorie społeczno-kulturowe w studiach feministycznych. Perspektywa socjologiczno-pedagogiczna, Poznań 1995.

Helias J., Jedlecka W., Urzeczywistnianie idei feminizmu w ogólnoświatowym dyskursie o kobietach, E-wydawnictwo. Prawnicza i Ekonomiczna Biblioteka Cyfrowa, Wrocław 2018.

Kowalska B. i in., Studia nad niepetnosprawnościq a wyobraźnia socjologiczna, „Studia Socjologiczne" 2014, no. 2.

Marys J.M., Feminist disability theory: domestic violence against women with a disability "Disability\&Society" 2007, no. 2.

Morris J., Feminism and Disability, "Feminist Review" 1993, no. 43.

Morris J., Introduction, [in:] Encounters with strangers. Feminist and disability, ed. J. Morris, The Women's Press, London 1996.

O'Toole C.J., Violence and sexual assault plague many disabled women, New Directions for Women 1990.

Ostrowska A., Niepełnosprawni w społeczeństwie 1993-2013, Wydawnictwo IFiS PAN, Warszawa 2010.

${ }^{34}$ Ibidem. 
Owens J., Exploring the critiques of the social model of disability: the transformative possibility of Arendt's nation of power, "Sociology of Health and Illness" 2015, no. 3.

Piątek K., Szanse i zagrożenia $w$ funkcjonowaniu kobiet $z$ niepetnosprawnością. Studium socjologiczne, [in:] Polscy niepetnosprawni. Pomiędzy deklaracjami a realiami, ed. B. Gąciarz, S. Rudnicki, D. Żuchowska-Skiba, Wydawnictwo AGH, Kraków 2015.

Pollock G., Polityki teorii: pokolenia $i$ geografie. Teoria feministyczna $i$ historie historii sztuki, translated by M. Bryl, "Artium Quaestiones" 1997, no. VIII,

Renzetti C.M., Curran D.J., Kobiety, mężczyźni i spoteczeństwo, translated by A. Gromkowska-Melosik, Wydawnictwo Naukowe PWN, Warszawa, 2005.

Silling Ch., Socjologia ciata, translated by M. Skowrońska, Wydawnictwo Naukowe PWN, Warszawa 2010.

Tilley Ch.M., Health Care for Women with Physical Disabilities: Literature Review and Theory, "Sexuality and Disability" 1998, no. 2.

Turner J.H., Struktura teorii socjologicznej. Wydanie nowe, Warszawa, 2004

Twardowski A., Społeczny model niepetnosprawności - analiza krytyczna, „Studia Edukacyjne" 2018, no. 48.

Wołowicz-Ruszkowska A., Zanikanie? Trajektorie tożsamości kobiet z niepetnosprawnością, Wydawnictwo Akademii Pedagogiki Specjalnej, Warszawa 2013.

Zygmunt A., Feminizm a symboliczna ideologia, „Oblicza Komunikacji” 2009, vol. 2. 